\title{
Schistosoma mansoni CIRCULATING POLYSACCHARIDE AND PROTEIN ANTIGENS RECOGNIZED BY SHEEP ANTISERA IN PATIENTS WITH DIFFERENT CLINICAL FORMS OF SCHISTOSOMIASIS BEFORE AND AFTER TREATMENT
}

\author{
Julia Maria COSTA-CRUZ (1), Sumie HOSHINO-SIIMIZU (2), Antonio Walter FERREIRA (3), Mario E. \\ CAMARGO (3), Thales de BRITO (3) \& Luiz Caetano da SILVA (3).
}

\begin{abstract}
SUMMARY
Two sheep antisera, one of which raised against polysaccharide (Po) and other against protein $(\mathrm{Pt})$ components of Schistosoma mansoni adult worms, were assessed by ELISA for their ability to detect circulating parasite antigens in patients with different clinical forms of chronic schistosomiasis mansoni. The former antiserum detected parasite antigens in liver granulomata and the latter in renal glomeruli from schistosomiasis patients and mice experimentally infected with S.mansoni. In general, the levels and/or positivity rate of circulating antigens and specific IgG antibodies were significantly higher in patients with hepatointestinal (HI) and hepatosplenic (HS) forms than in mild intestinal (I) forms. An association between Po antigens and clinical features of the disease was observed, as the level of these antigens was low $(137 \mathrm{ng} / \mathrm{ml})$ as well as the positivity rate $(7.9 \%)$ in patients with I forms; values that were intermediate $(593 \mathrm{ng} / \mathrm{ml}$ and $33.3 \%)$ in those with $\mathrm{HI}$ forms, and high $(1.563 \mathrm{ng} / \mathrm{ml}$ and $50.0 \%)$ in more severe HS forms. The $\mathrm{Pt}$ antigens were detected in the studied clinical forms not differing statistically but, the positivity rate was significantly higher in HS forms comparatively to I forms. The antisera studied revealed distinct circulating antigen profiles, and the prognostic value of $\mathrm{Po}$ and $\mathrm{Pt}$ antigens was suggested.
\end{abstract}

KEYWORDS: Chronic schistosomiasis; Circulating antigens; Chemotherapy.

\section{INTRODUCTION}

Schistosoma mansoni is a complex multicellular organism and its antigenic components are classified according to their role in terms of host protection, parasite protection, pathogenesis, immunodiagnosis, etc. ${ }^{2,15}$

In order to study several immunopathologic aspects of schistosomiasis mansoni associated with kidney damage and liver granulomata, we produced two antisera in sheep, one against adult worm protein $(\mathrm{Pt})$ antigens and the other against the worm polysaccharide fraction (Po). Parasite antigens were demonstrated in kidney deposits with $\mathrm{Pt}$ antiserum, and egg antigens in liver granulomata from chronic schistosomiasis patients and experimentally infected mice were detected with the Po antiserum 4,5,8,9. Moreover, both antisera have detected circulating antigens in experimental models 7,14 but thus far they have not been tested in schistosomiasis patients.

(1) Departamento de Patologia da Universidade Federal de Uberlândia/MG, Brasil.

(2) Instituto Adolfo Lutz. São Paulo/SP. Brasil.

(3) Instituto de Medicina Tropical de São Paulo. São Paulo/SP. Brasil.

Correspondence to: Dr. Antonio Walter Ferreira, Instituto de Medicina Tropical de São Paulo. Av. Dr. Enéas de Carvalho Aguiar, 470 - 05403-000 São Paulo/SP, Brasil. 
COSTA-CRUZ,J.M.;HOSHINO-SHIMIZU, S.; FERREIRA, A.W.; CAMARGO, M.E.; BRITO, T. de \& SILVA, L.C. da Schistosoma mansoni circulating polysaccharide and protein antigens recognized by sheep antisera in patients with different clinical forms of schistosomiasis before and after treatment. Rev. Inst. Med. trop. S. Paulo, 36(4): 321-325, 1994.

Since circulating antigens associated with the pathogenesis of human schistosomiasis may be difficult to detect and since chemotherapy transiently enhances antigenemia due to parasite destruction ${ }^{19}$, in the present study we tested the two antisera before and shortly after specific chemotherapy in patients with different clinical forms of chronic schistosomiasis.

\section{MATERIAL AND METHODS}

Patients - Thirty eight patients with chronic schistosomiasis were studied. All were excreting viable $S$. mansoni eggs, as detected by the KatoKatz method ${ }^{12}$. The patients were divided into 3 groups according to the clinical criteria of NEVES 17. The first group consisted of 21 patients with the intestinal (I) form, the second of 9 patients with the hepatointestinal (HI) form, and the third of 8 patients with the hepatosplenic (HS) form. Patients were treated with Praziquantel or Oxamniquine 8 administered as a single oral dose of $45 \mathrm{mg} / \mathrm{kg}$ and $15 \mathrm{mg} / \mathrm{kg}$, respectively. Serum samples were collected before and 2 and 8 days after treatment for groups $\mathrm{HI}$ and HS, and also 15 days after treatment for group I. All sera were aliquoted and stored at $-70^{\circ} \mathrm{C}$ until used.

Parasite antigen detection - A double antibody enzyme-immunosorbent assay (ELISA) was performed using immune sera to worm protein $(\mathrm{Pt})$ antigens and to polysaccharide (Po) components produced in sheep ${ }^{7}$. The gammaglobulin fraction was isolated from both antisera and from normal sheep serum by $1.56 \mathrm{M}$ ammonium sulphate precipitation and absorbed with a human gamma-globulin immunosorbent 1. Fractions obtained from immune $\mathrm{Pt}$ and Po sera were conjugated to horse-radish peroxidase by the method of NAKANE \& KAWAOI ${ }^{16}$. To obviate the interference of rheumatoid factor with the immunologic assay, all sera positive in the latex agglutination test for this factor (Behringwerke, Germany) were absorbed with human gamma-globulin immunosorbent, as previously described ${ }^{6}$. Briefly ELISA was performed as follows: the microplates were sensitized with the gamma-globulin fraction of the antiserum to Pt or Po incubated with patient's serum. The captured antigen was revealed by homologous peroxidase conjugate, and $\mathrm{H} 2 \mathrm{O} 2$ and o-dianisidine were used as substrate.

Antibody (IgG) detection - Immunoglobulin $\mathrm{G}$ antibodies to $S$. mansoni were detected in serum samples by the indirect immunofluorescence test (IFT) using cryostat sections of frozen adult worms ${ }^{11}$.

Statistical analyses - The Fisher test ${ }^{18}$ was applied to the data do determine differences in circulating antigen positivity rate between the I, HI and HS clinical forms of schistosomiasis before and after treatment. The over all antigen data obtained for the different clinical forms before and after treatment were compared by the Chi-squared test. ${ }^{18}$ The mean levels of Po and Pt circulating antigens, the geometric mean titers (GMT) of IgG antibodies transformed in $\log @$ as well as the egg counts were analysed by Student's $t$ test 13. The stipulated level of significance was $5 \%$ for all the statistical tests.

\section{RESULTS}

All the patients with $\mathrm{I}, \mathrm{HI}$ and $\mathrm{HS}$ forms of schistosomiasis mansoni were excreting viable eggs before treatment and their geometric mean egg counts were 153,710 and 400 per gram feces, respectively. These values did not differ statistically.

The circulating Po and Pt antigens were detected in the three studied groups of patients and their mean values $(\mathrm{ng} / \mathrm{ml})$ and positivity rate (\%) showed mostly a peak on the 2nd day after treatment. These findings, however, were similar when compared to the data from the period before and 8 th day after treatment. Also no difference was seen when the statistical tests were applied to the over all data in which the clinical forms were not taken into account (Table 1).

The data obtained for each clinical form of schistosomiasis, irrespective the factors time and treatment (Table 2), revealed statistical differences as follows. 
The Po antigen levels in patients with $\mathrm{HI}$ and HS forms were significantly higher than that of I forms $(t=3.003 ;$ d.f. $=88$ for $I \times H I$ and $t=4.292 ;$ d.f. $=85$, for IxHS), and patients with HS forms in turn showed higher Po antigen levels than those with $\mathrm{HI}$ forms $(\mathrm{t}=1.883 ;$ d.f. $=49)$. Apparently the $\mathrm{Pt}$ antigen levels from $\mathrm{HI}$ forms are higher than other clinical forms (Table 2), however, the statistical analysis showed no difference.

The positivity rate of Pt antigens, however, was higher in the group of patients with HS forms than that in $I$ forms $\left(X^{2}=7.074 ;\right.$ d.f. $\left.=1\right)$ and it did not differ from that of patients with $\mathrm{HI}$ forms.

The IgG antibodies to S.mansoni antigens were detected in all studied patients and their titers tended to increase after treatment. The GMT of antibodies from patients with $\mathrm{HI}$ and HS forms were also higher than that of patients with $I$ forms $(t=2.626 ;$ d.f. $=88$ for $\mathrm{IxHI}$ and $\mathrm{t}=3.667 ;$ d.f. $=85$ for IxHS); whereas the GMT of those with $\mathrm{HI}$ and $\mathrm{HS}$ forms were close.

\section{DISCUSSION}

Two sheep antisera were studied in patients with I, HI and HS forms of chronic schistosomiasis mansoni and circulating Po and Pt antigens detected by these antisera were prone to increase in serum two days after specific chemotherapy, decreasing thereafter.

\section{TABLE 1}

Schistosoma mansonl circulating polysaccharide (Po) and protein (Pt) antigens and specific IgG and antibodies in sera from 38 patients with chronic schistosomiasis collected before, 2 nd and 8 th day after treatment

\begin{tabular}{|c|c|c|c|c|c|}
\hline \multirow{2}{*}{$\begin{array}{c}\text { Period } \\
\text { of } \\
\text { Time }\end{array}$} & \multicolumn{4}{|c|}{ Antigens } & \multirow{2}{*}{$\begin{array}{c}\text { IgG } \\
\text { Antibodie } \\
(\mathrm{GMT})^{\star \star}\end{array}$} \\
\hline & $\begin{array}{c}\mathrm{Po}^{\star} \\
(\mathrm{ng} / \mathrm{ml})\end{array}$ & $\%$ & $\underset{(\mathrm{ng} / \mathrm{ml})}{\mathrm{Pt}^{\star}}$ & $\%$ & \\
\hline \multicolumn{6}{|l|}{ Before } \\
\hline Treatment & 487 & 21.1 & 1,108 & 21.1 & 7.2 \\
\hline 2nd Day & & & & & \\
\hline $\begin{array}{l}\text { After } \\
\text { Treatment }\end{array}$ & 795 & 26.3 & 2,655 & 23.7 & 7.2 \\
\hline $\begin{array}{l}\text { 8th Day } \\
\text { After } \\
\text { Treatment }\end{array}$ & 353 & 21.1 & 1,116 & 18.4 & 7.7 \\
\hline $\begin{array}{l}\text { Overall } \\
\text { data }\end{array}$ & 545 & 22.8 & 1,626 & 21.1 & 7.4 \\
\hline
\end{tabular}

* Mean values

** GMT - Geometric mean titers

Egg counts did not differ among the three groups of patients indicating the worm burden is not affecting the observed immunologic profiles.

The Pt antigens were found and their levels did not differ significantly between the patients with mild I forms and more severe HI and HS

TABLE 2

Schistosoma mansoni circulating polysaccharide (Po) and protein (Pt) antigens and specific IgG antibodies in sera from 38 patients with different clinical forms of chronic schistosomiasis from a period before to 8th day after treatment

\begin{tabular}{|c|c|c|c|c|c|c|}
\hline \multirow{2}{*}{$\begin{array}{c}\text { Clinical } \\
\text { Form }\end{array}$} & \multirow{2}{*}{$\begin{array}{c}\text { No } \\
\text { of } \\
\text { Sera }\end{array}$} & \multicolumn{4}{|c|}{ Antigens } & \multirow{2}{*}{$\begin{array}{c}\text { IgG } \\
\text { Antibodies } \\
(\mathrm{GMT})^{\star *}\end{array}$} \\
\hline & & $\begin{array}{c}\mathrm{Po}^{*} \\
(\mathrm{ng} / \mathrm{ml})\end{array}$ & $\%$ & $\begin{array}{c}\mathrm{Pl}^{\star} \\
(\mathrm{ng} / \mathrm{ml})\end{array}$ & $\%$ & \\
\hline Intestinal (I) & 63 & 137 & 7.9 & 1,240 & 14.3 & 6.8 \\
\hline Hepatointestinal (HI) & 27 & 593 & 33.3 & 3,148 & 22.2 & 7.8 \\
\hline Hepatosplenic (HS) & 24 & 1,563 & 50.0 & 929 & 37.5 & 8.5 \\
\hline Overall data & 114 & 545 & 22.8 & 1,626 & 21.1 & 7.4 \\
\hline
\end{tabular}

* Mean values

$\star \star$ GMT - Geometric mean titers 
forms (Table 2) but, particularly in those with HS forms, these antigens were seen in significantly higher frequency than in I forms. In a previous study by our group ${ }^{8}, \mathrm{Pt}$ antigens were suggested to be associated with renal lesions in chronic and severe schistosomiasis. Thus, the persistance of $\mathbf{P t}$ antigens in $\mathrm{HI}$ and $\mathrm{HS}$ forms is thought as an early signal for the pathogenesis of renal lesion.

The other antiserum under investigation detected Po antigens in high levels and more frequently among patients with HS forms of the disease, followed by HI forms which in turn had higher values than those of I forms. These data indicate a positive correlation between the Po antigens and the severity of schistosomiasis mansoni on the standpoint of clinical features. This antiserum did not reveal parasite antigens in the kidney but reacted with egg antigens in liver granulomata 5 . Thus, Po antigens seems to be associated to the liver pathology of the disease, and their persistance in patients might be indicative of a worse prognosis, in the same way as $\mathrm{Pt}$ antigens are related to renal damage.

The overall positivity rate of $\mathrm{Po}$ and $\mathrm{Pt}$ antigens were higher in $\mathrm{HI}$ and $\mathrm{HS}$ forms when compared to I forms. These data confirm previous reports ${ }^{3,10}$ suggesting impaired clearence of parasite antigens and immune complexes in the HS form of schistosomiasis. Although showing glomerular affinity, Pt antigens appear to also originate immune complexes which are efficiently cleared in mild forms.

The finding of Po and $\mathrm{Pt}$ antigens mostly in schistosomiasis patients with $\mathrm{HI}$ and HS forms is consistent, implying the potential prognostic value of these antigens. Nevertheless aspects related to proteinuria and hematuria have to be better checked in those clinical forms of the disease.

Thus, the antisera studied showed different antigen profiles in schistosomiasis mansoni patients, which also differed from those we had previously detected in experimental S.mansoni infections ${ }^{7}$.

\section{RESUMO}

Antígenos polissacarídicos e protéicos circulantes de Schistosoma mansoni reconhecidos por antissoros de carneiro em pacientes com diferentes formas clínicas da esquistossomose antes e após o tratamento.

Dois antissoros produzidos em carneiros, um dos quais contra a fração polissacarídica (Po) e outro contra componentes protéicos $(\mathrm{Pt})$ de vermes adultos de Schistosoma mansoni, foram avaliados quanto ao seu desempenho na deteç̧ão de antígenos parasitários circulantes em pacientes com diferentes formas clínicas da esquistossomose mansônica crônica, através de um ensaio imunoenzimático, (ELISA). O primeiro antissoro revelava antígenos parasitários no granuloma hepático e o segundo, nos glomérulos renais de pacientes com esquistossomose mansônica, bem como em camundongos experimentalmente infectados pelo $S$. mansoni. Em geral, os niveis bem como a positividade, de antígenos circulantes e anticorpos IgG específicos foram significativamente mais elevados nos pacientes com formas hepatointestinais (HI) e hepatosplênicas (HS) do que em pacientes com formas amenas intestinais (1). Foi observada uma associação entre os antígenos $P_{0}$ e as características clínicas da doença, em vista do nivel destes antígenos se encontrar abaixo $(137 \mathrm{ng} / \mathrm{ml})$, assim como sua positividade $(7.9 \%)$ em pacientes com formas I, intermediários $(593 \mathrm{ng} / \mathrm{ml}$ e $33.3 \%)$ naqueles com formas HI e altos $(1.563 \mathrm{ng} / \mathrm{ml} \mathrm{e} 50.0 \%)$ nas formas HS. Os níveis de antígenos $\mathrm{Pt}$ não diferiram estatisticamente nas três formas clínicas estudadas, mas a positividade foi significantemente maior nas formas HS em comparação com as formas I. Os antissoros estudados revelaram perfis distintos de antígenos circulantes e o valor prognóstico dos antígenos Po e Pt foi aventado.

\section{ACKNOWLEDGEMENTS}

We are grateful to Mr. Almir Robson Ferreira and to Mrs. Ceci Corrêa Godoi de Angelis Prazias for technical assistance during the preparation of this manuscript. 


\section{REFERENCES}

1. AVRAMEAS, S. \& TERNYNCK, T. - The cross-linking of protein with glutaraldehyde and its use for the preparation of immunosorbent. Immunochemistry, 6: $53-66,1969$.

2. BARSOUN, R.S. - Schistosomal glomerulopathies. Kidney Int., 44: 1-12, 1993.

3. BOUT, D.; SANTORO, F. \& CAPRON, A. - Détection des immunecomplexes dans la bilharziose. Méd. mal. infect., 12: 631-636, 1975.

4. BRITO, T.; HOSHINO-SHIMIZU, S.; SILVA, L.C. et al. - Immunopathology of experimental schistosome (S.mansoni) egg granulomas in mice. Possible defense mechanisms mediated by local immune complexes. J. Path., 140: 17.28, 1983.

5. BRITO, T.; HOSHINO-SHIMIZU, S.; YAMASHIRO, E. \& SILVA, L.C. - Chronic human schistosomiasis mansoni: schistosomal antigens, immunoglobulins and complement C3 detection in the liver. Liver, 5: 64-70, 1985.

6. CAMARGO, M.E.; LESER, P.G. \& ROCCA, A. Rheumatoid factor as a cause for false positive IgM antitoxoplasma fluorescent test: a technique for specific results. Rev. Inst. Med. trop. S. Paulo, 14: 310-313, 1972.

7. FERREIRA, A.W.; CALDINI, A.L.M.; HOSHINOSHIMIZU, S. \& CAMARGO, M.E. - Immunoenzymatic assay for the detection of Schistosoma mansoni antigens in serum of mice harbouring bisexual and unisexual worm infections. J. Helminth., 53: 189-194, 1979.

8. HOSHINO-SHIMIZU, S.; BRITO, T.; KANAMURA, H.Y. et al. - Human schistosomiasis: Schistosoma mansoni antigen detection in renal glomeruli. Trans. roy. Soc. trop. Med. Hyg., 70: 492-496, 1976.

9. HOSHINO-SHIMIZU, S. - Esquistossomose mansônica: anticorpos e antígenos parasitários no sangue e no rim, e alteraçes renais, em camundongos experimentalmente infectados. São Paulo, 1977. (Dissertaçāo de Mestrado - Faculdade de Medicina da Universidade de Sāo Paulo).
10. JONGE, N.; RABELLO, A.L.; KRINGGER, F.W. et al. - Levels of the schistosome circulating anodic and cathodic antigens in serum of schistosomiasis patients in Brazil. Trans. roy. Soc. trop. Med. Hyg., 85: 756759, 1991.

11. KANAMURA, H.Y.; HOSHINO-SHIMIZU, S.; CAMARGO, M.E. \& SILVA, L.C. - Class specific antibodies and fluorescent staining patterns in acute and chronic forms of schistosomiasis mansoni. Amer. J. trop. Med. Hyg., 28: 242-248, 1979.

12. KATZ, N.; ChaVeS, A. \& PELlegrino, I. - A simple device for quantitative stool thick smear technique in schistosomiasis mansoni. Rev. Inst. Med. trop. S. Paulo, 14: 397-400, 1972.

13. LAMOTE, M. - Estatística biologica: principios fundamentais. Barcelona, Toray-Masion, 1981.

14. LOPES, J.D.; MOURA, A.A.B.; CAMPOS, R. et al. Circulating antigens, antibodies and glomerular immune complexes in mice with unissexual Schistosoma mansoni infections. Rev. Inst. Med. trop. S. Paulo, 23: $155-160,1981$.

15. MAIZELS, M. - Parasite antigens. In: BENNKF, 3.M., ed. - Parasites: immunity and pathology. New York, Taylor \& Francis, 1990. p. 23-39.

16. NAKANE, P.K. \& KAWAOI, A. - Peroxidase labelled antibody. A new method of conjugation. J. Histochem. Cytochem., 22: 1084-1091, 1974.

17. NEVES, J. - Quadro clínico. In: CUNHA, A.S., ed. Esquistossomose mansoni. São Paulo, Sarvier/Editora da USP, 1970. p. 131-191.

18. SIGEL, S., ed. - Estatística no paramétrica. São Paulo, McGraw-Hill, 1975.

19. SILVA, L.C.; CAMARGO, M.E.; HOSHINOSHIMIZU, S. et. al. - Serum antibody and eosinophil changes after treatment of human Manson's schistosomiasis with Niridazole or Hycanthone. Rev. Inst. Med. trop. S. Paulo, 13: 121-130, 1971.

Recebido para publicação em 26/11/1993 Aceito para publicação em 20/04/1994 